\title{
ISOLATION OF COPPER AND STREPTOMYCIN RESISTANT PHYTOPATHOGENIC PSEUDOMONAS SYRINGAE FROM LAKES AND RIVERS IN THE CENTRAL NORTH ISLAND OF NEW ZEALAND
}

\author{
J.L. VANNESTE ${ }^{1}$, D.A. CORNISH ${ }^{1}$, J. YU ${ }^{1}$, R.J. BOYD ${ }^{1}$ \\ and C.E. MORRIS ${ }^{2}$
}

\begin{abstract}
${ }^{I}$ The Horticulture and Food Research Institute of New Zealand Limited, Ruakura Research Centre, Private Bag 3123, Hamilton, New Zealand ${ }^{2}$ INRA, UR 407 Pathologie Végétale, F-84140 Montfavet, France

Corresponding author: JVanneste@hortresearch.co.nz
\end{abstract}

\begin{abstract}
Plant pathogenic strains of Pseudomonas syringae were isolated from lakes and rivers in the central North Island of New Zealand. These strains were identified by their ability to produce a fluorescent pigment on a modified King's B medium, by their ability to cause a hypersensitive reaction when infiltrated into tobacco plant and by the absence of a cytochrome c oxidase. Different aspects of the protocol used to isolate these strains have been assessed. Some of the strains isolated, and in some cases the majority of them, were resistant to copper and/or streptomycin. Significantly, these plant pathogenic bacteria were isolated from waterways in areas where no agriculture or horticulture is present and waterways used for crop irrigation. These results suggest that natural waterways could be a source of inoculum of plant pathogenic bacteria, and a source of genes that confer streptomycin resistance and/or copper resistance to these bacteria.
\end{abstract}

Keywords: bacterial ecology, copper resistance, streptomycin resistance.

\section{INTRODUCTION}

Control of plant bacterial diseases is difficult for a number of reasons, including the unpredictability of outbreaks. Epiphytotics can occur where previously no or little inoculum was thought to be present. The source of the primary inoculum of these epiphytotics is not always easy to determine, especially for pathogenic bacteria that are good epiphytes. This is the case of one of the most economically important bacterial plant pathogens: Pseudomonas syringae (Hu et al. 1999; Noble et al. 2006). Pseudomonas syringae contains more than 50 pathovars, which collectively can cause symptoms on several hundreds of different plant species. The ecology of this important bacterial species outside the agronomic context is just beginning to be unravelled (Morris et al. 2007; Morris et al. 2008). Based on results obtained in Europe and in the USA, Morris et al. (2008) proposed that this pathogen is linked with the water cycle. Such a link could explain some of the geographic distribution of different strains and pathovars of P. syringae.

This project aimed to determine whether strains of $P$. syringae could be isolated from rivers and lakes from the Central North Island of New Zealand. Two different water systems were chosen: the Waikato River and the Whakapapanui Stream. The Waikato River and its associated lakes (Taupo, Whakamaru and Karapiro) represent a complex system that goes through some non-cultivated and cultivated lands, while the Whakapapanui stream is fed by melt water from Mount Ruapehu and does not cross cultivated lands. The presence of genes that confer resistance to streptomycin and/or 
copper sulphate in the bacteria isolated from these rivers and lakes was also determined as the presence of such genes in natural waterways could help explain their distribution among plant pathogenic and plant epiphytic bacteria.

\section{MATERIALS AND METHODS \\ Collection of water samples and isolation of bacteria}

Water samples (Table 1) were collected from natural waterways into 1 litre sterile bottles, which were opened and closed only when fully immersed at the collection sites. Water samples were labelled to differentiate collection date and post-collection treatments. When one sample was divided in two lots, to allow comparison between techniques, each lot was assigned a letter at the end of the label (e.g. 3.1a and 3.1b). The samples were brought to the laboratory and, with the exception of samples $3.1 \mathrm{a}$ and $3.1 \mathrm{~b}$, were kept overnight at either room temperature or $4^{\circ} \mathrm{C}$. Before the samples were further processed, the total numbers of bacteria present in the samples was estimated by spreading $100 \mu \mathrm{l}$ of each sample on plates of Tryptic Soy Agar (TSA) (Oxoid, Basings, Hampshire, England). These plates were incubated overnight at $28^{\circ} \mathrm{C}$ before the number of colonies was counted. The samples were then filtered through a $0.22 \mu$ m type GV membrane (Millipore). When $500 \mathrm{ml}$ had been filtered, or less if the filter became blocked, the filter was washed in $5 \mathrm{ml}$ of the water that had been filtered. In some cases, to prevent the $0.22 \mu \mathrm{m}$ membrane from being blocked too soon, a GF/A glass microfibre filter (Whatman International Ltd, Maidstone, England) was used to pre-filter the samples. The exact volume filtered through the $0.22 \mu \mathrm{m}$ membrane was recorded to enable calculation of the concentration of bacteria in the original sample. Table 1 presents the date and location of the samples, as well as the temperature at which the samples were kept when they were not processed on the day of collection, and whether a pre-filter was used.

The resuspended bacterial suspension $(100 \mu \mathrm{l})$ was plated on KBC medium (Mohan \& Schaad 1987). This is a modified King's B medium (King et al. 1954) that prevents the growth of a number of saprophytic organisms, and is more selective than King's B for plant pathogenic bacteria. Strains of $P$. syringae produce the same fluorescent pigment on KBC as they do on King's B medium, so KBC can be used to selectively isolate strains of P. syringae (Mohan \& Schaad 1987; Morris et al. 2007).

\section{Characterisation of the bacteria}

To determine whether the isolates were pathogenic to plants, their ability to induce a hypersensitive reaction when injected into tobacco plants was assessed (Klement 1963). This ability was tested as described previously (Vanneste et al. 1990). Inoculum prepared in sterile water was infiltrated in the intercostal area of young and fully expanded leaves using an 18-gauge sterile needle. Absence of a cytochrome c oxidase, a criterion that differentiates $P$. syringae from other plant pathogenic fluorescent Pseudomonas, was determined using Test Oxidase ${ }^{\mathrm{TM}}$ (Pro-Lab Diagnostic, Richmond Hill, ON, Canada). For this assay, the strain of P. fluorescens A506 was used as positive control and the strain of $P$. syringae pv. syringae ICMP3523 was used as a negative control. For some strains, production of levan, production of an arginine dihydrolase under anaerobic conditions and/or the ability to hydrolyse esculin were also determined. These experiments were carried out as described by Lelliot et al. (1966). Inability to utilise arginine is a characteristic shared by all strains of $P$. syringae while production of levan and hydrolysis of esculin is a characteristic of some pathovars only.

Resistance to copper or streptomycin was determined as described previously (Vanneste et al. 2005). Bacterial strains were toothpicked individually onto Luria agar (Invitrogen Life Technologies Ltd) (24 strains per plate) and left to grow at $28^{\circ} \mathrm{C}$ for 2 days. They were then transferred using a handheld replicator onto plates of minimal medium Ceria 132 (Vanneste et al. 1992) containing $250 \mathrm{mg} /$ litre or $500 \mathrm{mg} /$ litre of copper sulphate $\left(\mathrm{CuSO}_{4} .5 \mathrm{H}_{2} \mathrm{O} ; \mathrm{BDH}\right.$ Laboratory Supplies) or streptomycin $(100 \mathrm{ppm})$. The strains of P. syringae FF5 (Sundin \& Bender 1993) and P. syringae 7B40 (Sundin \& Bender 1996) were used as a negative and a positive control respectively. Resistance to copper sulphate or streptomycin was determined after 2 days of incubation at $28^{\circ} \mathrm{C}$. 


\section{RESULTS AND DISCUSSION}

For each of the 19 water samples analysed, the concentration of total bacteria, as determined by the number of bacteria that grew on TSA, and the concentration of bacteria that produced a fluorescent pigment on KBC, are presented in Table 1. The concentration of viable bacteria ranged from $9.0 \times 10^{2}$ to $4.2 \times 10^{8} \mathrm{cfu} /$ litre. However, for samples collected at one time from one location, the variation was much smaller. For samples 4.1a, 4.3a, 4.5, 4.6 and 4.7, which were all kept overnight at room temperature, the concentration of bacteria that grew on TSA ranged from $9.0 \times 10^{6}$ to $4.2 \times 10^{8} \mathrm{cfu} /$ litre. For samples $4.1 \mathrm{~b}$ and $4.3 \mathrm{~b}$, which were kept overnight at $4^{\circ} \mathrm{C}$, the concentration varied from $3.5 \times 10^{6}$ to $5.0 \times 10^{6} \mathrm{cfu} /$ litre. For these samples, the variation in concentration of bacteria that produced a pigment on KBC was even smaller (Table 1).

The number of bacteria recovered on TSA was always higher when the sample had been kept overnight at room temperature rather than at $4^{\circ} \mathrm{C}$. For sample $4.1 \mathrm{a}$, which was kept overnight at room temperature, the concentration of total bacteria was $1.5 \times 10^{7} \mathrm{cfu} /$ litre, but the concentration of total bacteria for the same sample kept at $4^{\circ} \mathrm{C}$ (sample $4.1 \mathrm{~b}$ ) was only $5.0 \times 10^{6} \mathrm{cfu} /$ litre. A similar difference was found between samples $4.3 \mathrm{a}$, which was kept at room temperature, and sample $4.3 \mathrm{~b}$, which was kept at $4^{\circ} \mathrm{C}$ $\left(9.0 \times 10^{6}\right.$ and $3.5 \times 10^{6} \mathrm{cfu} /$ litre respectively). The same trend was observed for samples collected from the Waikato River. The concentration of total bacteria was higher in samples $3.3 \mathrm{a}$ and $3.3 \mathrm{~b}$, which were kept at room temperature $\left(7.0 \times 10^{6} \mathrm{cfu} /\right.$ litre $)$, than from samples $3.5 \mathrm{a}$ and $3.5 \mathrm{~b}$, which were kept at $4^{\circ} \mathrm{C}\left(5.0 \times 10^{5} \mathrm{cfu} / \mathrm{litre}\right)$. These differences were also observed when comparing the number of strains that grew and produced a fluorescent pigment on KBC. More bacteria were recovered when the samples had been kept overnight at room temperature rather than when kept at $4^{\circ} \mathrm{C}$ (Table 1$)$. These differences could simply reflect that bacteria were able to multiply when kept at room temperature but not at $4^{\circ} \mathrm{C}$. This is supported by the fact that the concentration of total bacteria in samples from the Waikato River were similar when the samples were processed the same day they had been collected (samples 3.1a and 3.1b), or when they were kept overnight at $4^{\circ} \mathrm{C}$ (samples $3.5 \mathrm{a}$ and $3.5 \mathrm{~b}$ ) (Table 1).

Some water samples had a high content of material in suspension that blocked the $0.22 \mu \mathrm{m}$ membrane and limited the volume of water that could be filtered. To prevent blockage, some samples were pre-filtered through a GF/A glass microfibre filter. The number of bacteria recovered on KBC plates after being pre-filtered was almost identical to that recovered from the same sample that had only been filtered through a $0.22 \mu \mathrm{m}$ membrane (Table 1).

Bacteria from samples 2.1 and $3.1 \mathrm{a}$ to $3.5 \mathrm{~b}$ that produced a fluorescent pigment on $\mathrm{KBC}$ were further characterised (Table 1). A total of 15 strains was found to induce a hypersensitive reaction when inoculated in tobacco plants, indicating they are plant pathogenic. They were oxidase negative, which indicated that they were most probably strains of $P$. syringae. This was confirmed for four strains by comparing the DNA sequence of their 16SrDNA gene with sequences deposited in international databases, using BLAST 2.2.1 (Altschul et al. 1997).Ten of these strains were also unable to utilise arginine, indicating that they lacked an arginine dihydrolase, which is a characteristic of plant pathogenic Pseudomonas. Those 10 strains could also hydrolyse esculin, but only two were able to produce levan.

Not all strains that produced a fluorescent pigment on KBC were able to induce a hypersensitive reaction on tobacco. Furthermore, the number of viable P. syringae in a sample might be higher than that recorded using KBC. The recovery of some strains of P. syringae on $\mathrm{KBC}$ is known to be poor: $0.00003 \%$ in the worst cases (Morris et al. 2008). However, this semi-selective medium has proven useful for comparing populations of potentially pathogenic bacteria from different samples.

A large proportion of the strains that grew and produced a fluorescent pigment on $\mathrm{KBC}$ were resistant to copper or to streptomycin (Table 1), and these strains were found in every sample examined. Every strain isolated on KBC from Lake Taupo on $25 \mathrm{March}$ 2007 (water samples 4.1 to 4.7) was tested for resistance to copper and or streptomycin. 


\begin{tabular}{|c|c|c|c|c|c|c|c|c|c|c|c|c|c|c|c|c|c|c|c|c|}
\hline 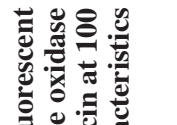 & 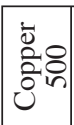 & $\stackrel{m}{\curvearrowright}$ & $\triangleq$ & $\frac{o}{\lambda}$ & 㫐 & $\stackrel{ \pm}{ \pm}$ & $\frac{\Delta}{\delta}$ & c) & & & $\frac{n}{f}$ & $\hat{a}$ & & \multicolumn{6}{|c|}{$\frac{\infty}{\stackrel{m}{\sigma}}$} & U \\
\hline 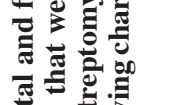 & $\mid \begin{array}{l}\dot{0} \\
\tilde{a} \\
\tilde{z} \\
\tilde{z}\end{array}$ & $\stackrel{m}{\curvearrowright}$ & $\stackrel{-}{\lambda}$ & $\frac{0}{m}$ & 帛 & $\stackrel{\searrow}{\forall}$ & $\frac{ \pm}{\infty}$ & है & & & $\frac{n}{n}$ & $\lesssim$ & & \multicolumn{6}{|c|}{$\frac{n}{\frac{0}{\sigma}}$} & $\begin{array}{l}\tilde{0} \\
\stackrel{\Xi}{\Xi}\end{array}$ \\
\hline 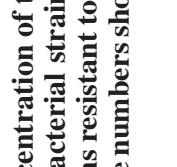 & 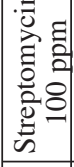 & $\stackrel{m}{\partial}$ & $\stackrel{-}{\mathbf{v}}$ & $\stackrel{\wp}{o}$ & 㫐 & $\stackrel{ \pm}{=}$ & $\frac{\Xi}{\partial}$ & $\stackrel{5}{c}$ & & & $\frac{n}{n}$ & $\lesssim$ & & \multicolumn{6}{|c|}{ 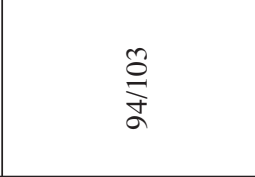 } & 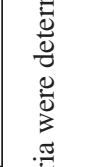 \\
\hline 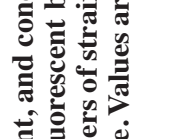 & 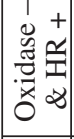 & 气 & 点 & 乬 & 点 & 乬 & $\frac{ \pm}{\infty}$ & $\stackrel{5}{\frac{1}{2}}$ & & & $\begin{array}{c}\text { d } \\
\text { d }\end{array}$ & $\lesssim$ & & \multicolumn{6}{|c|}{ 㝋 } & 䒕 \\
\hline 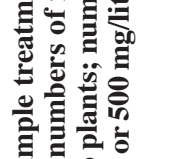 & 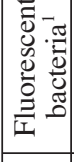 & 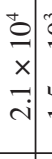 & $\mid \begin{array}{c}3 \\
0 \\
x \\
n \\
-1\end{array}$ & $\begin{array}{l} \pm \\
\stackrel{0}{x} \\
\square \\
-\end{array}$ & 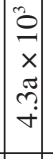 & $\begin{array}{l}3 \\
\stackrel{0}{x} \\
n \\
n\end{array}$ & $\begin{array}{l}0 \\
0 \\
x \\
n\end{array}$ & $\left|\begin{array}{l}0 \\
0 \\
x \\
\infty\end{array}\right|$ & $\begin{array}{l}0 \\
\times \\
0 \\
0\end{array}$ & $\begin{array}{l}0 \\
\frac{0}{x} \\
-2\end{array}$ & $\left|\begin{array}{l}0 \\
0 \\
x \\
\infty\end{array}\right|$ & $\begin{array}{l}0 \\
0 \\
x \\
n\end{array}$ & $\begin{array}{l}0 \\
x \\
n \\
-\end{array}$ & 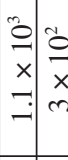 & 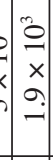 & $\mid \begin{array}{c}3 \\
0 \\
x \\
m\end{array}$ & $\begin{array}{l}0 \\
0 \\
\times \\
\times \\
0 \\
-\end{array}$ & $\begin{array}{l} \pm \\
\stackrel{0}{0} \\
\times \\
-\end{array}$ & $\begin{array}{l}0 \\
0 \\
x \\
\infty\end{array}$ & 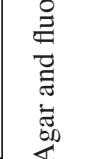 \\
\hline 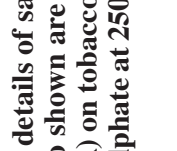 & 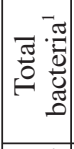 & $\begin{array}{c}0 \\
0 \\
x \\
x \\
\dot{0} \\
0\end{array}$ & $\begin{array}{l}0 \\
0 \\
x \\
0 \\
-1\end{array}$ & $\begin{array}{l}0 \\
\times \\
\square \\
=\end{array}$ & 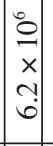 & $\begin{array}{l}n \\
0 \\
x \\
b \\
i\end{array}$ & $\begin{array}{l}\text { J0 } \\
\times \\
0 \\
a\end{array}$ & $\begin{array}{c}n \\
3 \\
x \\
x \\
n \\
n\end{array}$ & & 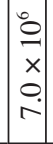 & & $\begin{array}{l}3 \\
0 \\
x \\
0 \\
\dot{0} \\
\end{array}$ & & \begin{tabular}{l|l}
$\tilde{0}$ & 0 \\
$x$ & 0 \\
$x$ & $x$ \\
$n$ & 0 \\
- & $n$
\end{tabular} & 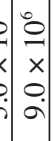 & $\mid \begin{array}{c}0 \\
0 \\
x \\
n \\
n \\
m\end{array}$ & $\begin{array}{c}0 \\
0 \\
\times \\
\times \\
\infty \\
\infty \\
-1\end{array}$ & \begin{tabular}{l}
$\infty$ \\
0 \\
$\times$ \\
\hdashline \\
$\dot{+}$
\end{tabular} & $\left|\begin{array}{c}0 \\
0 \\
x \\
\infty \\
\dot{m}\end{array}\right|$ & 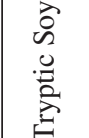 \\
\hline 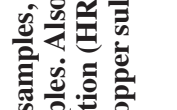 & D. & ㅇ. & z & Z & z) & 之 & 之े & $\stackrel{3}{2}$ & ż & $\approx$ & ż & $\stackrel{2}{3}$ & z & $z$ & 点 & z & z & z) & ż & 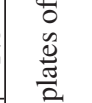 \\
\hline 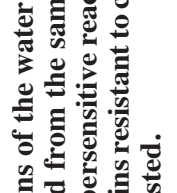 & 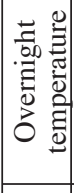 & $\begin{array}{l}u \\
\stackrel{0}{+}\end{array}$ & Oे & $\begin{array}{l}\text { Uे } \\
\stackrel{\circ}{+}\end{array}$ & \begin{tabular}{|l|} 
\\
0 \\
$\dot{\gamma}$
\end{tabular} & $\begin{array}{l}\text { ○े } \\
\stackrel{+}{+}\end{array}$ & $\begin{array}{l}ن \\
\stackrel{\circ}{+}\end{array}$ & 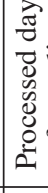 & & 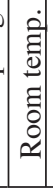 & : & $\begin{array}{l}ن \\
\stackrel{\circ}{+}\end{array}$ & $\begin{array}{l}0 \\
\circ \\
\end{array}$ & 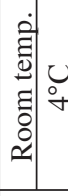 & 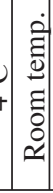 & \begin{tabular}{|l|} 
\\
$ن$ \\
$\circ$
\end{tabular} & 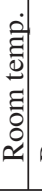 & 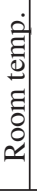 & 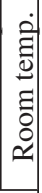 & 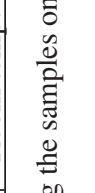 \\
\hline 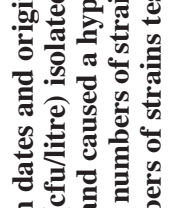 & 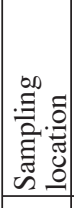 & 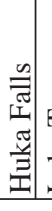 & 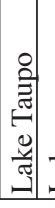 & 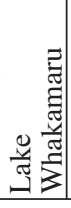 & 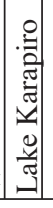 & 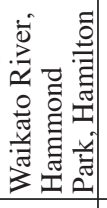 & 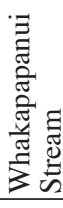 & & & 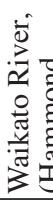 & 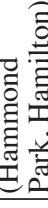 & & & & 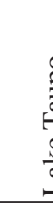 & & & & & 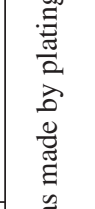 \\
\hline 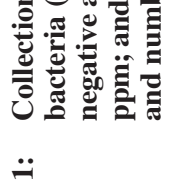 & 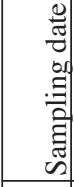 & & & 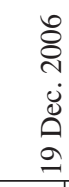 & & & 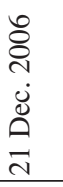 & & & 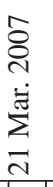 & & & & & 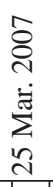 & & & & & 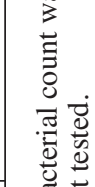 \\
\hline & 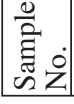 & $\exists$ & $\stackrel{-1}{-1}$ & $\stackrel{9}{-}$ & 古 & n? & i & $\ddot{m}$ & & $\begin{array}{c}m \\
m \\
m\end{array}$ & $\bar{m}$ & ஸ̆ & nே. & \begin{tabular}{c|c}
$\stackrel{\pi}{+}$ & 0 \\
&
\end{tabular} & 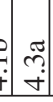 & $\begin{array}{l}\vec{m} \\
\dot{\nabla}\end{array}$ & $\begin{array}{l}n \\
\dot{\nabla}\end{array}$ & $\dot{\forall}$ & $\stackrel{7}{+}$ & 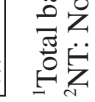 \\
\hline
\end{tabular}


Ninety-one percent of these strains were streptomycin resistant and up to $42 \%$ were resistant to high concentrations of copper sulphate $(500 \mathrm{mg} /$ litre $)$. Previously it has been shown that resistance to copper in strains of Pseudomonas isolated from different orchards from New Zealand was coded by genes carried by plasmids, and that some of these plasmids also carried genes for streptomycin resistance and were able to be transferred by conjugation to new bacteria (Vanneste et al. 2005; Vanneste et al. 2008). Using PCR primers developed by Vanneste et al. (2008), at least one of the strains tested in the present study carried genes similar to those found earlier (data not shown).

Plant pathogenic bacteria belonging to the species Pseudomonas were isolated from three lakes and two river systems in the Central North Island of New Zealand. Strains of $P$. syringae were also isolated from rivers in France, Italy and in the USA (Morris et al. 2007; Morris et al. 2008). These results support the hypothesis that the life history of P. syringae is linked to the water cycle, as proposed by Morris et al. (2008). In this scenario, rain and melt water containing cells of $P$. syringae, feed streams and rivers that bring those cells of $P$. syringae in contact with wild and cultivated plants. The subsequent multiplication of these bacteria as pathogens or epiphytes provides a huge inoculum, part of which might forms aerosols that can be taken up by clouds. The ability of some of these bacteria to induce ice nucleation might help the formation of rain and/or snow and explains the presence of these bacteria in rain and snow (Morris et al. 2008). Although not all those steps have been demonstrated in New Zealand, it can be concluded that water from rivers and lakes is a likely source of plant pathogenic bacteria. Furthermore, natural waterways are also likely to be a source of genes conferring streptomycin and/ or copper resistance in populations of plant bacterial pathogens.

\section{ACKNOWLEDGEMENTS}

We thank The Horticulture and Food Research Institute of New Zealand Limited for their support.

\section{REFERENCES}

Altschul SF, Madden TL, Schaffer AA, Zhang J, Zhang Z, Miller W, Lipman DJ 1997. Gapped BLAST and PSI-BLAST: a new generation of protein database search programs. Nucleic Acid Research 25: 3389-3402.

Hu F-P, Young JM, Jones DS 1999. Evidence that bacterial blight of kiwifruit, caused by a Pseudomonas sp., was introduced into New Zealand from China. Journal of Phytopathoglogy 147: 89-97.

King EO, Ward MK, Raney DE 1954. Two simple media for the demonstration of pyocyanin and fluorescin. Journal of Laboratory Clinical Medicine 44: 301-307.

Klement Z 1963. Rapid detection of the pathogenicity of phytopathogenic pseudomonads. Nature 199: 299-300.

Lelliot RA, Billing E, Hayward AC 1966. A determinative scheme for the fluorescent plant pathogenic Pseudomonads. Journal of Applied Bacteriology 29: 470-489.

Mohan SK, Schaad NW 1987. An improved agar plating assay for detecting Pseudomonas syringae pv. syringae and $P$. s. pv. phaseolicola in contaminated bean seed. Phytopathology 77: 1390-1395.

Morris CE, Kinkel LL, Xiao K, Prior P, Sands DC 2007. Surprising niche for the plant pathogen Pseudomonas syringae. Infection, Genetics and Evolution 7: 84-92.

Morris CE, Sands DC, Vinatzer BA, Glaux C, Guilbaud C, Buffiere A, Yan S, Dominguez H Thompson BM 2008. The life history of the plant pathogen Pseudomonas syringae is linked to the water cycle. The International Society for Microbial Ecology Journal 1: 1-14.

Noble DH, Cother EJ, Hailstones DL, Flack M, Oxspring L, Hall B 2006. Characterisation of Pseudomonas syringae strains associated with a leaf disease of leek in Australia. European Journal of Plant Pathology 115: 419-430. 
Sundin GW Bender CL 1993. Ecological and genetic analysis of copper and streptomycin resistance in Pseudomonas syringae pv. syringae. Applied and Environmental Microbiology 59: 1018-1024.

Sundin GW Bender CL 1996. Molecular analysis of closely related copper- and streptomycin- resistance plasmids in Pseudomonas syringae pv. syringae. Plasmid 35: $98-107$.

Vanneste JL, McLaren GF, Yu J, Cornish DA, Boyd D 2005. Copper and streptomycin resistance in bacterial strains isolated from stone fruit orchards in New Zealand. New Zealand Plant Protection 58: 101-105.

Vanneste JL, Paulin JP, Expert D 1990. Bacteriophage Mu as a genetic tool to study Erwinia amylovora pathogenicity and hypersensitive reaction on tobacco. Journal of Bacteriology 172: 932-941.

Vanneste JL, Voyle MD, Yu J, Cornish DA, Boyd RJ, McLaren GF 2008. Copper and streptomycin resistance in Pseudomonas strains isolated from pipfruit and stone fruit orchards in New Zealand. In: Fatmi M, Collmer A, Iacobellis NS, Mansfield JW, Murillo J, Schaad NW, Ullrich M ed. Pseudomonas syringae pathovars and related pathogens- Identification, Epidemiology and Genomics. Springer, Dordrecht, the Netherlands. Pp. 81-90.

Vanneste JL, Yu J, Beer SV 1992. Role of antibiotic production by Erwinia herbicola Eh252 in biological control of Erwinia amylovora. Journal of Bacteriology 174: 2785-2796. 